This item was submitted to Loughborough's Research Repository by the author.

Items in Figshare are protected by copyright, with all rights reserved, unless otherwise indicated.

\title{
Maxillofacial prostheses challenges in resource constrained regions
}

PLEASE CITE THE PUBLISHED VERSION

http://dx.doi.org/10.1080/09638288.2017.1390697

\section{PUBLISHER}

Taylor \& Francis

\section{VERSION}

AM (Accepted Manuscript)

\section{PUBLISHER STATEMENT}

This work is made available according to the conditions of the Creative Commons Attribution-NonCommercialNoDerivatives 4.0 International (CC BY-NC-ND 4.0) licence. Full details of this licence are available at: https://creativecommons.org/licenses/by-nc-nd/4.0/

\section{LICENCE}

CC BY-NC-ND 4.0

\section{REPOSITORY RECORD}

Tetteh, Sophia, Richard J. Bibb, and Simon J. Martin. 2017. "Maxillofacial Prostheses Challenges in Resource Constrained Regions". figshare. https://hdl.handle.net/2134/27323. 


\title{
Title: Maxillofacial Prostheses Challenges in Resource Constrained Regions
}

\begin{abstract}
Background: This study reviewed the current state of maxillofacial rehabilitation in resourcelimited nations.

Method: A rigorous literature review was undertaken using several technical and clinical databases using a variety of key words pertinent to maxillofacial prosthetic rehabilitation and resource-limited areas. In addition, interviews were conducted with researchers, clinicians and prosthetists that had direct experience of volunteering or working in resource-limited countries.
\end{abstract}

Results: Results from the review and interviews suggest rehabilitating patients in resourcelimited countries remains challenging and efforts to improve the situation requires a multifactorial approach.

Conclusion: In conclusion, public health awareness programmes to reduce the causation of injuries and bespoke maxillofacial prosthetics training programmes to suit these countries, as opposed to attempting to replicate Western training programmes. It is also possible that usage of locally sourced and cheaper materials and the use of low-cost technologies could greatly improve maxillofacial rehabilitation efforts in these localities.

\section{Keywords:}

facial prosthetic, resource-limited areas, maxillofacial, facial disfigurement, rehabilitation, 


\section{Implications for Rehabilitation}

More information and support needs to be provided to maxillofacial defect/injuries patients and to their families or guardians in a culturally sensitive manner by governments.

The health needs, economic and psychological needs of the patients need to be taken into account during the rehabilitation process by clinicians and healthcare organizations.

The possibility of developing training programs to suit these resource limited countries and not necessarily follow conventional fabrication methods must be looked into further by educational entities.

\section{Background}

Facial deficiencies/disfigurements or injuries are usually caused by congenital malformation or anomalies, trauma or treatment of neoplasms [1,2]. These deficiencies, disfigurements or injuries will generally involve soft and hard tissues of the face extending from the frontal bone superiorly to the mandible inferiorly and vary from soft tissue lacerations to complex fractures of the facial skeleton [3] . Facial appearance is the most significant factor in appearance and perception of self [4] . Injuries in the facial region require more care than wounds elsewhere in the body because of the desired aesthetic results [5] and functionality. Injuries in the facial region pose serious public health problems such as severe morbidity, loss of functionality, disfigurement, psychological trauma and significant financial cost [6-8].

Over the last few decades, the number of patients requiring facial prostheses has increased, mostly due to an increase in elderly populations and improving cancer survival rates that involve facial tissues [9]. Furthermore, accessibility to facial prostheses for patients in many parts of the world are either none or extremely limited [9]. The stigma and socio-economic effects in resource-limited countries can be tragic to the individual and their families, often hampering their prospects of social and economic development, hence the provision of custom-made prostheses by voluntary assistance overseas and training of local staff is essential [10]. Additionally, issues of cost, time, technical difficulties and the lack of skilled Maxillofacial Prosthetists \& Technicians (MPTs also known as anaplastologists) required for 
the prosthetic fabrication cannot be ignored [11]. Aside from the specific challenges to developing nations or resource-limited regions, the shortcomings of materials currently in use include discolouration, weakening margins, inadequate mechanical properties, degradation due to ultraviolet (UV) light and many others. Many of these shortcomings are exaggerated in resource-limited regions (very high levels of UV in sub-Saharan Africa for example). The complexities in fabrication plus a lack of an existing ideal material compounds the challenges in resource-limited areas. Currently, advances in healthcare focus on the needs of the developed nations (North America, Western Europe, Japan), which does not cater for developing countries due to their underdeveloped infrastructure, little investment and few healthcare workers. Hence, frugal technology must be designed specifically for the world's poorest people that specifically meet the needs of patients in these countries [12]. Furthermore, the donation of second-hand or surplus devices from hospitals in high income countries contributes to the excess of unusable technologies in developing countries [12] and whilst some utility may be found in some prosthetic limb devices the individual nature of facial prosthetics makes this approach untenable. This review identifies opportunities, barriers and future needs of maxillofacial rehabilitation deficiencies in resource limited countries.

\section{Methods}

A literature search was completed to review maxillofacial prosthetic rehabilitation in resource-limited regions. The keywords and search engines used are summarised in table 1 below. Furthermore, the Boolean operator was also used to combine and narrow down the possible search results. Additionally, electronic alerts such as 'zetoc' were scheduled weekly to notify of up to date relevant news and information around the search area. The search commenced from October 2015 to November 2016.

\section{[Insert Table 1 Here]}


Additionally, interviews were conducted with prosthetists, clinicians and researchers that have either worked or volunteered in developing countries. A snowballing sampling technique was utilised in recruiting participants. The participants had worked or volunteered in resourcelimited area for at least 4 weeks in the field of maxillofacial prosthetic rehabilitation. The purpose of the study was explained to the participants and the interview questions regarding their experiences were sent out prior to the interview. Information gathered was either through informal and formal and interviews were held by telephone or in person. The interviews lasted between 30 to 60 minutes.

\section{Results}

Overall, participants had been working in this field from 5 to 25 years. Participants had volunteered or worked in resource limited countries namely Bangladesh, India, Vietnam, Peru, South Africa and Brazil as seen in table 2.

\section{[Insert table 2 here]}

These countries have been defined by Development Assistance Committee (DAC) of the Organisation for Economic Cooperation and Development (OECD) as being least developed country (Bangladesh); Lower middle Income countries and territories (India, Vietnam) and Upper Middle Income Countries and Territories (Brazil, Peru, South Africa). The interviews provided information on prosthetic materials, environmental and climatic factors; technical knowhow; modern fabrication methods; improvements in materials and societal issues. Some of the material properties essential for resource-limited areas as stated by the participants are material longevity, tolerance to varying weather conditions, colour stability, training programmes and biocompatibility. Furthermore, issues of maintenance to enhance service life of prostheses are essential. Conversely, this is dependent on usage and care. Environmental factors such as pollution, extreme temperatures and high UV radiation were identified as having a negative effect on the prostheses but the long-term effects were unknown. 
In these resource-limited regions maxillofacial prosthetics expertise ranges from very little to none in comparison to other health fields and no formal training is available. This lack of local training programmes necessitates the development of training that follows existing training modules in developed countries. Residents were receptive and keen to learn the construction and fabrication process as this provides an economic livelihood. Furthermore, traditional fabrication methods as well as new technologies can be utilised for fabrication and construction of the maxillofacial prostheses in resource-limited areas. Nonetheless, personnel need to be trained efficiently in issues of equipment maintenance and accessibility to affordable prosthetic materials and consumables must be considered.

\section{Aetiological Factors of Maxillofacial Defects/Injuries}

\section{Trauma}

Common causes of maxillofacial injuries by trauma are road traffic accidents, falls, sports and industrial accidents, falls from heights, school and domestic accidents involving children, birth injuries, gunshots and bomb blasts [4,13-15]. These can further be seen in table 3. In developing countries, road traffic accidents have been reported as the most common cause of maxillofacial injuries and fractures [5,15-24]. These accidents have been attributed to continuous economic expansion [25] ; increase in urban population due to substantial drift of people to the urban areas from the rural districts; poor road conditions; inadequate vehicle maintenance; haphazard (unqualified) driving and persons driving under the influences of alcohol [13]. Nonetheless, the source of maxillofacial injuries and fractures varies from country to country and even within the same country depends on the prevailing socioeconomic, cultural and environmental factors [16,20,22,26] .

\section{[Insert Table 3 here]}

\section{Cancer}

Cancer of the facial region is one of the five leading sites of cancer occurrence [27] and oral and pharyngeal cancer grouped together are the sixth most common cancer in the world [28] . 
The incidence of oral cancer varies from different regions of the world with the highest rates reported in South East Asia especially India, Pakistan and Sri Lanka [28,29]. Cancer occurrences have been associated with geographically related environmental factors, genetic differences and differences in biological properties of causative organisms [30]. The cancer epidemic in developed countries and increasingly in developing countries is due to the combined effect of ageing populations and the high or increasing prevalence of cancer risk factors [31]. Furthermore, low income and disadvantaged groups are generally more exposed to avoidable risk factors such as environmental carcinogens, alcohol, infectious agents and tobacco use [32]. Head and neck cancers have been associated with known aetiological and predisposing factors such as tobacco consumed in betel quid or pan consisting of tobacco mixed with chopped areca nut [33] and chronic alcohol use, ingestion of smoked fish, infections especially by viruses such as the human papillomavirus has been detected in some substantial benign oral lesions [34]; dietary deficiencies, pollution [29,32] and inactive lifestyles [32]. Socio-economic factors such as underutilisation of hospital services due to either inability by some patients to afford hospital costs, lack of adequate health services in some areas or traditional beliefs has led to the higher incidences of orofacial cancer in resource-limited regions worldwide.

\section{Malformations}

Congenital defects are a diverse group of disorders of prenatal origin that can be caused by single gene defects, chromosomal disorders, multifactorial inheritance, environmental teratogens and micronutrients deficiencies [35-37]. In resource-limited regions congenital anomalies due to environmental exposures have been attributed to low socioeconomic and educational levels; increased incidence of malnutrition, mineral and vitamin deficiencies [iodine and folic acid] and intrauterine infections; lack of environmental protection policies; high level of environmental pollution and unsafe working conditions during gestation; access to medicines without medical indication nor prescriptions and the common use of home remedies of unknown composition [37].

The birth prevalence of congenital abnormalities in developing nations is underestimated by deficiencies in diagnostic capabilities and unreliable or non-existent medical records and health statistics [37], continued prevalence of infectious diseases and malnutrition [38]. 


\section{Psychological Issues towards Maxillofacial Defects/Abnormalities}

The aesthetics of facial structures are used by humans [rightly or wrongly] to determine, not only a person's beauty but his or her personality, intelligence, social class, trustworthiness, social skill, popularity and overall goodness [39-41]. Patients with maxillofacial defects, malformations or injuries have functional deficits and an enormous psychological stress that requires rehabilitation. These persons experience greater social avoidance and are generally perceived as possessing more negative personality characteristics. Although these struggles often manifest as clinical depression, no correlation between the maxillofacial defects and depression severity has been observed [42]. Furthermore, each patient requiring a facial prosthesis has different needs. Most will experience a phase of adjustment to the loss; preparation for the provision of a facial prostheses [including the expectations of the treatment]; adjustment to the reaction of other people after the provision of the prosthesis and long-term coping with their new facial prostheses [43]. The effect of missing a facial feature on social interaction acts at three levels with intimate relationships showing the greatest impact, interactions with family and friends requiring the least modification and interactions with acquaintances and people outside the person's immediate social circle marked by awkwardness [43].

\section{Socio Cultural Issues towards Maxillofacial Defects/Abnormalities}

Cultural beliefs, assumptions and myths have an impact on patients with maxillofacial defects or malformations, their families and their communities. The profound impact on the patient's life depends on the location, variability in severity, visibility and numerous personal, social and situational characteristics [44]. Different cultures might sometimes lead to considerable variation in beliefs about causation of defects such as supernatural forces, evil spirits or ancestral spirts [45]. Additionally, causation of these defects/malformations has been attributed to an act of God; to an act of the devil; evil spirits and witchcraft; retribution for mother's sin; to reincarnation, evil men of the night; curse placed on the family possibly traceable to the ancestors of the affected child; a curse from God; evil attack; effect of black magic; presence of fibroid in the womb; or reincarnation of an accident victim [46,47]. In some communities, orofacial anomalies are condemned and affected infants were "removed from the tribe or cultural unit and left to die in the surrounding wilderness”, a practice that still prevails today in certain African tribes [38]. These cultural beliefs generally lead to 
marginalisation and stigmatization; which eventually precipitates patients to seek healthcare services.

\section{Support for Maxillofacial Defects/Deformity [Local/ Foreign]}

\section{Non-Governmental Organizations}

Institutional support for maxillofacial rehabilitation is usually provided by the trauma units within a hospital. Most of these hospitals are located within urban centres that might not be easily accessible to patients that are not within the immediate geographic region. Furthermore, late presentations of maxillofacial injuries/malformations to hospitals mean that more extensive care will be needed.

There are a number of charities and non-governmental organisations such as Facing the World [48]; International Ocular Prosthetic Services (IOPS) [49]; Comprehensive Community Based Rehabilitation in Tanzania [CCBRT] Disability Hospital [50] and many others who volunteer their time and skills overseas in training local staff in the provision of services in maxillofacial prostheses [10]. Sometimes these services are provided to the patients at little or no cost.

\section{Issues of Maxillofacial Prostheses in Resource Limited}

\section{Lack of Training and Personnel}

Overall, there is little to no expertise in maxillofacial prosthetic fabrication depending on the resource-limited area under investigation in comparison to the provision of other medical services.

Current conventional fabrication methods require long hours in the laboratory and clinic for both the patients and clinicians [51-53]. Maxillofacial prosthetist training programmes usually involve lengthy time periods [51,54], and training must cover technical skills, functionality, aesthetics of the prostheses as well as the psychological care of the patient $[51,53]$. Most maxillofacial prosthetists have training in dental technology followed by post- 
qualification training in a maxillofacial department [55]. A highly trained and skilled specialist is required to sculpt a form accurately replicating the lost anatomy and to handle the time consuming technical fabrication process [56]. The lack of training programmes necessitates training modules to be developed although it is not obligatory to follow the training programmes found in developed countries. Most resource-limited countries also do not have structured formal training as found in developed countries in the field of maxillofacial prostheses.

\section{Lack of "Ideal" Materials}

Currently, there exists no ideal material for the fabrication of maxillofacial prostheses. However, the principal material of preference has been silicone elastomers [57-60]. The commonly reported problems of prosthetic materials are discolouration, texture; lack of longevity; material degradation [sunlight, moisture, wind, dust, pollutants and temperature] [61-63]; margin deterioration and decreased mechanical adequacy such as tear strength $[56,60,65-69]$.

Margin deterioration of the prostheses occurs due to cosmetics, adhesives, strong solvents or cleansers used alongside the prostheses causing it to degrade; losing the fine thin edges that seamlessly blends with the anatomic human skin and the extrinsic colouring [51]. Most current materials have a low tear strength and poor wettability [68]. Hence, it is important to have a material with adequate tensile properties and appropriate hardness [68].

Colour instability has been attributed to the pigments used intrinsically and extrinsically as well as the effects of the climate and environmental conditions. Colour matching of the prostheses to the anatomic human skin has its own unique challenges due to the variability and subjectivity of the process [69]; very small quantities of pigments are added to the prosthetic material intrinsically or extrinsically until an acceptable colour is obtained $[53,69]$.

Environmental, climatic factors such as such as UV exposure [daylight], dust, extreme temperatures as well as lifestyle can result in physical and chemical changes to the maxillofacial prostheses material. These physical and chemical changes within the material can lead to changes in the mechanical and optical properties of the polymer [70]. Chemical changes that might lead to chemical degradation may occur between the maxillofacial prosthetic material and any fluid or substance it comes into contact with such as sweat, 
adhesives, detergents and many others. The lack of an ideal material for the fabrication of maxillofacial prostheses creates challenges in the development of an ideal maxillofacial prostheses material especially for resource-limited areas.

Prostheses are exposed to mucosa, moist air and skin secretions, subsequently multilayer biofilm formation can occur on the surfaces in contact with the skin [71-73]. Furthermore, nutritional support either extrinsically or intrinsically [for example residual salts from sweating, sebaceous secretions, traces of petroleum jelly applied to facilitate donning] from within the prostheses will sustain further growth of these micro-organisms [72]. The prosthesis surface can then harbour microorganisms within the pores the material if they are not removed by appropriate washing [71,74]. Some problems associated with microbial colonization are black or brown stains on the surface of the prostheses, offensive odours and tissue infections [71].

\section{Surgical Process}

In resource-limited areas, late presentation of maxillofacial deformities or injuries by patients are a major problem in achieving acceptable cosmetic outcomes [19] causing the severity of these injuries to increase. Previous studies on the quality of life of patients with head and neck cancer revealed levels of emotional anguish, physical limitations, loss of self-esteem, disturbances in body image and damage to social relations $[4,57,75]$. Repair of facial defects by modern surgical techniques has produced satisfactory results, when the defect is favourable for the surgical process. Nevertheless, modern surgical techniques have limitations such as the local condition of the tissue, susceptibility to recurrence of the original malignant lesion; an unhealthy vascular condition at the site of deformity; the size and extent of the deformity; age of the patient or inability to meet the time and expense of the operation [76]. Therefore, when the patient has some or all of the above conditions, the alternative for restoration is the facial prosthetic (maxillofacial prosthesis) [27]. Furthermore, the paucity of suitably qualified surgical teams in this field emphasises the need to have more people trained in fabricating and constructing the maxillofacial prostheses.

\section{Fabrication and Construction Challenges}


Current methods adopted in the conventional or traditional fabrication process are initial consultation and treatment planning; facial impression taking; mould construction; colour matching and extrinsic colouring and detailing [53,51]. The fabrication process includes several complex phases that are labour intensive and time consuming in which the final result depends on the experience and skill of the clinician [53,77]. The facial impression process is required to record the anatomic area of defect. Commonly experienced challenges whilst taking impressions are technical sensitivity of the material, working time, setting time; training and experience needed to handle the materials; weight of impression material can cause the residual tissue to deform, which can lead to distortion; economic cost of large usage of impression material [53,56,51].

\section{The Way Forward in Maxillofacial Prostheses in Resource Limited}

\section{Public Health Awareness}

Traumatic accidents leading to facial injuries in developing countries can be reduced if improved road conditions, motor vehicle safety inspections, public awareness programmes and mandatory seatbelt wearing is implemented as seen as the reduction of road traffic accidents in developed countries [15,78, 79].

Overall, cancer survival rates have increased as a result of early diagnosis, improvements in surgical techniques and post-treatment therapies. This has further led to a rise in the number of patients that need treatment. In resource-limited countries, socio-economic factors such as underutilisation of hospital services due to either unaffordability of hospital costs, paucity of adequate health service provision or cultural beliefs has led to higher incidences of orofacial cancer worldwide. Further, these regions lack cancer registries as well as an absence of a comprehensive death registration. Hence, the real incidence or prevalence of cancers is still not fully realised [28]. The development or creation of cancer registries in resource-limited areas is essential, i.e. both hospital and population based cancer registries. Population based cancer registries exist in various parts of the world but the greater proportion are in developed countries (Cancer registries). In developing countries, these registries tend to cover urban areas where healthcare services are of a better quality. This might give insight into the exact 
healthcare needs that can then be eventually used for cancer control, epidemiological research, public health programme planning and ultimately patient care improvement.

Some preventive measures to reduce malformations during birth are access to family planning programmes that include the encouragement to complete reproduction before 35 years of age; periconceptional supplementation of folic acid; access to adequate prenatal care; including nutrition; control of maternal infections and avoidance of teratogens and expansion of rubella immunisation.

A patient's beliefs and cultural background is essential to a successful transmission of new ideas, techniques and practices. This will lead to a comprehensive care plan for the patient to suit their distinctiveness. Patients' expectations from care delivery and reaction[s] to treatment and treatment outcome are determined largely or partly by what they believe. Furthermore, the treatment options might call for greater collaboration to share information between modern medical practitioners and traditional healers in a culturally sensitive manner [45]. Patients' rehabilitation is related to the psychological attitude in gaining confidence as well as understanding and cooperation between patient and clinician. During the rehabilitation process, the clinician must not exhibit any feelings of surprise or repulsion, especially with the patient present but rather should be professional, full of optimism with regards to the treatment options and the results to be expected.

\section{Training Programmes}

The availability of appropriate training programmes in maxillofacial prosthetic fabrication and construction in resource-limited regions is crucial. The training of a prosthetist should satisfy the demands of technical; functional; psychological and aesthetic needs and requirements [51]. Training programmes need not replicate those in developed countries, which are structured, formal and regulated. However, training should be of comparable depth and quality. Training of local residents in pursuing maxillofacial prosthetics could serve as a career choice; multiple variation of medical services provision as well as development of human resource capacity. Also, new low-cost technologies such as three-dimensional photography (3D scanning) computer aided design or computer aided manufacturing (CAD/CAM) systems can be incorporated in the fabrication and construction process to simplify, streamline and possibly automate some of the steps involved in creating prostheses $[56,80]$. 
Current research efforts in maxillofacial prostheses fabrication and construction has incorporated computer aided design/computer aided manufacturing (CAD/CAM); rapid prototyping and additive manufacturing, also known as 3D Printing [9,56,77,79-84] . Furthermore, this will require people being trained in using these technologies effectively and efficiently.

Additionally, the equipment needed for the fabrication of prostheses needs to be considered. Commonly equipment must be properly maintained and meet expected industry standards. Likewise, other factors such as ensuring the proper usage, maintenance of this equipment are constant power supply, clean water supply and the provision of affordable materials and consumables. Current methods utilised for fabrication in developed countries can be adapted for use in developing countries. Moreover, some of the traditional equipment utilised might need to be adapted to these resource-limited areas.

\section{“Ideal” Material[s]}

The ideal material should replicate the missing facial tissue to match a patient's articulate functions of mastication, speech resonance and facial gesture. The prostheses need to satisfy certain conditions such as biocompatibility; non-toxic; non-allergenic; simple fabrication process; adequate physical and mechanical properties; good degradation properties due to physical and mechanical factors and lastly superior adhesive properties.

Research efforts to improve the physical and mechanical characteristics of the existing materials such as nano-fillers, nano-particles, tulle and many others are ongoing. Results from the addition of nano-particles revealed improved mechanical properties [60,86,87] . Furthermore, the incorporation of tulle to the silicone elastomer improved the margin strength of the prostheses $[88,89]$. The addition of intrinsic pigments significantly influenced the dynamic properties of the silicone elastomers at low frequencies of 0.5 to $2.5 \mathrm{~Hz}$ at room temperatures [90]. It should however be noted that the nano-particles and fillers were added in different ratios and concentrations to various commercially available silicone elastomers.

Also new experimental materials have been developed with a formulation consisting of high and low molecular weight vinyl-end-blocked polydimethylsiloxane, surface treated hydrophobic silica; hydride functional silicone polymer and lastly a platinum complex [91]. The new experimental materials had superior tear strength, low hardness and comparable 
viscosity in contrast to commercially available materials. Furthermore, new polydimethylsiloxane material formulations comprising of a tin catalyst, silane cross-linking agents, hydrophobic silica filler and hydroxy-end-blocked poly-dimethylsiloxane with improved mechanical properties in comparison to commercially available materials. Additionally, silicone hollow microsphere composites were created utilising expancel hollow spheres and hollow silicone dioxide microspheres [92]. This new material revealed an improvement in the density, Shore A hardness and breaking elongation of the materials. However, there was degradation in tensile strength, tear strength and dynamic mechanical properties while the contrary was observed in the hollow silicon dioxide microspheres. The silicone materials and the additives remain expensive and difficult to obtain in resourcelimited countries.

\section{Use of Technology}

The adoption of new technologies and techniques will greatly enhance the fabrication and construction of these prostheses. The use of technology in the construction and fabrication of the maxillofacial prostheses can aid in easing the complex steps involved in fabricating prostheses, shorten time periods in creating the prostheses; improve accuracy and reduce effort for the patient [56,51]. New technology options have been incorporated into the fabrication and construction of maxillofacial prostheses. These technologies can be grouped into software and hardware systems. The use of magnetic resonance imaging (MRI) scans; lasers scanning; 3D photography/photogrammetry and Computed Tomography (CT) scans have been reported to have been utilised in the field of maxillofacial prostheses [56,7981,92-96]. Also, the development of software such as Solidworks (Dassault Systems), Geomagic FreeForm Modelling Plus CAD; Mimics (Materials, Belgium); Geomagic Studio (3D Systems), ProEngineer (PTC Creo), Autodesk 123D (Autodesk) has been used in producing 3D models of the maxillofacial prostheses [56,80,81,94]. The use of low cost hardware and software or a simplified fabrication process might be utilised in developing countries such as using photogrammetry by mobile device and free software such as Autodesk 123D Catch [56] and using a low cost desktop 3D printer in fabricating (scanning printing polishing casting) a soft prostheses [80]. In addition, simplifying the fabrication process, as was developed combining optical three dimensional acquisition, reverse engineering and 
rapid prototyping for mould production [98]. This reduces the dependence of the prosthetist whilst the efficiency of the fabrication process is increased.

\section{Conclusions}

Currently, a great deal of advancement is still needed in the field of maxillofacial prosthetics in resource-limited regions as indicated in the prior sections. The three main themes in improving or accelerating work in the field of maxillofacial prostheses are in material development, manufacturing processes and training. The creation of new materials with improved properties that mimic the anatomic human skin whilst meeting the environmental and cost demands of resource-limited regions will be crucial to advancing and improving maxillofacial prostheses. In addition, the utilisation of digital techniques might favour standardising the manufacturing process protocols associated with the fabrication and construction of maxillofacial prostheses as it eliminates some of the skills and or labour required by current conventional practices. The increasing availability of low cost technologies has the potential to improve maxillofacial prosthetic provision in resourcelimited regions. The development of bespoke and appropriate training programmes for resource-limited areas must also be explored and should not necessarily aim to replicate the training provided developed countries.

As this review was limited to seeking expert clinical opinions and not region and or nation specific issues further work is needed in each specific resource limited area to fully understand the unique challenges faced by maxillofacial defect/deformity patients and clinicians. This could be achieved through surveys, questionnaires or interviews or longitudinal studies. Longitudinal studies can provide more information and detailed insights to specific challenges faced by patients and clinicians especially in terms of issues including which defects are most challenging, immediate versus delayed rehabilitation; surgical defects and many others. 


\section{Acknowledgements}

This work was supported by the Schlumberger Foundation, Faculty for the future grant for ST's doctoral studies. The authors thank the staff at the Maxillofacial Clinic at Queen's Medical Centre, Nottingham University Hospital.

\section{Declaration of Interest}

The authors report no declarations of interest.

\section{References}

1. Beder OE. Surgical and maxillofacial prosthesis. [Internet]. Cumberlege G, editor. Oxford University Press; 1949. Available from: http://hdl.handle.net/2027/mdp.39015055665700

2. Beumer J, Curtis TA, Firtell DN. Maxillofacial Rehabilitation. 1979;333-64.

3. Abbas I, Fayyaz M, Shah I, Khan MA, Qazi SH, Munir N, et al. Demographic distribution of maxillofacial fractures in Ayub Teaching Hospital: 7-year review. J Ayub Med Coll Abbottabad. 2009;21(2):110-2.

4. Hill CM, Eppley BL, Thomas DW, Bond SE, Monaghan AM, Dover MS. Etiology and Prevention of Craniomaxillofacial Trauma. In: Maxillofacial Trauma and Esthetic Facial Reconstruction [Internet]. 
Elsevier; 2012. p. 3-18. Available from:

http://linkinghub.elsevier.com/retrieve/pii/B9781437724202000015

5. Schaftenaar E, Bastiaens GJ, Simon EN, Merkx MA. Presentation and management of maxillofacial trauma in Dar es Salaam, Tanzania. East Afr Med J. 2009;86(6):254-8.

6. Bai S-Z, Feng Z-H, Gao R, Dong Y, Bi Y-P, Wu G-F, et al. Development and application of a rapid rehabilitation system for reconstruction of maxillofacial soft-tissue defects related to war and traumatic injuries. Mil Med Res [Internet]. 2014;1:11. Available from:

http://www.ncbi.nlm.nih.gov/pubmed/25722869\%5Cnhttp://www.pubmedcentral.nih.gov/articlerender.f cgi?artid=PMC4340674

7. Dibaie A, Raissian S, Ghafarzadeh S. Evaluation of maxillofacial traumatic injuries of forensic medical center of ahwaz, Iran, in 2005. Pakistan J Med Sci. 2009;25(1):79-82.

8. Zandi M, Khayati A, Lamei A, Zarei H. Maxillofacial injuries in western Iran: A prospective study. Oral Maxillofac Surg. 2011;15(4):201-9.

9. M Zardawi F. Investigation of Elastomer Infiltration into 3D Printed Facial Soft Tissue Prostheses. Anaplastology [Internet]. 2015;4(1):3-7. Available from: http://omicsonline.org/openaccess/investigation-of-elastomer-infiltration-into-d-printed-facial-soft-tissue-prostheses-21611173.1000139.php?aid=36251

10. Haylock C. Specialist outreach clinics in primary care and rural hospital settings ( Cochrane Review ) Assistance in developing a custom-made prosthetic eye service Community Eye Health Journal article competition winners. Community Eye Heal J. 2006;19(58):2020.

11. Valauri AJ. Maxillofacial Prosthetics. Aesthetic Plast Surg [Internet]. 1982;6:159-64. Available from: http://www.ncbi.nlm.nih.gov/pubmed/6587611

12. Howitt P, Darzi A, Yang GZ, Ashrafian H, Atun R, Barlow J, et al. Technologies for global health. Lancet. 2012;380(9840):507-35.

13. Adekeye EO. The pattern of fractures of the facial skeleton in Kaduna, Nigeria. A survey of 1,447 cases. Oral Surgery, Oral Med Oral Pathol. 1980;49(6):491-5.

14. Shayyab M, Alsoleihat F, Ryalat S, Khraisat A. Trends in the Pattern of Facial Fractures in Different Countries of the World. Int J Morphol. 2012;30(2):745-56.

15. Ugboko VI, Odusanya SA, Fagade OO. Maxillofacial fractures in a semi-urban Nigerian teaching hospital. Int J Oral Maxillofac Surg [Internet]. 1998;27(4):286-9. Available from: http://www.sciencedirect.com/science/article/pii/S0901502705806162

16. Adeyemo WL, Ladeinde AL, Ogunlewe MO, James O. Trends and characteristics of oral and maxillofacial injuries in Nigeria: a review of the literature. Head Face Med [Internet]. 2005;1:7. Available from: http://www.pubmedcentral.nih.gov/articlerender.fcgi?artid=1277015\&tool=pmcentrez\&rendertype=abstr act

17. Bali R, Sharma P, Garg A, Dhillon G. A comprehensive study on maxillofacial trauma conducted in Yamunanagar, India. J Inj Violence Res. 2013;5(2):108-16.

18. Brasileiro BF, Passeri LA. Epidemiological analysis of maxillofacial fractures in Brazil: A 5-year prospective study. Oral Surgery, Oral Med Oral Pathol Oral Radiol Endodontology. 2006;102(1):28-34. 
19. Chalya PL, McHembe M, Mabula JB, Kanumba ES, Gilyoma JM. Etiological spectrum, injury characteristics and treatment outcome of maxillofacial injuries in a Tanzanian teaching hospital. J Trauma Manag Outcomes [Internet]. 2011;5(1):7. Available from: http://www.traumamanagement.org/content/5/1/7

20. Kamulegeya A, Lakor F, Kabenge K. Oral maxillofacial fractures seen at a Ugandan tertiary hospital: a six-month prospective study. Clinics (Sao Paulo). 2009;64(9):843-8.

21. Khitab U, Ansari SR, Khan A, Khan MT. Occurrence and Characteristics of Maxillofacial Injuries - a Study. Pakistan Oral Dent J. 2010;30(1):57-61.

22. Leles JLR, Santos EJ, Jorge FD, Silva ET, Leles CR, dos Santos EJ, et al. Risk factors for maxillofacial injuries in a Brazilian emergency hospital sample. J Appl Oral Sci [Internet]. 2010;18(1):23-9. Available from: http://www.scielo.br/scielo.php?script=sci_arttext\&pid=S1678-77572010000100006

23. Shah SGS, Robinson I, AlShawi S. Developing medical device technologies from users' perspectives: a theoretical framework for involving users in the development process. Int J Technol Assess Health Care. 2009;25(4):514-21.

24. Ukpong DI, Ugboko VI, Ndukwe KC, Gbolahan OO. Health-related quality of life in Nigerian patients with facial trauma and controls: a preliminary survey. Br J Oral Maxillofac Surg. 2008;46(4):297-300.

25. Adebayo ET, Ajike OS, Adekeye EO. Analysis of the pattern of maxillofacial fractures in Kaduna, Nigeria. Br J Oral Maxillofac Surg. 2003;41(6):396-400.

26. Shah, Amjad; Shah, Ali Adnan; Salam A. Maxillofacial Fractures: Analysis of Demographic Distribution in 320 Patients. Pakistan Oral Dent J. 2006;26(2):235-8.

27. Guttal KS, Naikmasur VG, Rao CB, Nadiger RK, Guttal SS. Orofacial rehabilitation of patients with post-cancer treatment--an overview and report of three cases. Indian J Cancer [Internet]. 2010;47(1):5964. Available from: http://www.ncbi.nlm.nih.gov/pubmed/20071792

28. Warnakulasuriya S. Global epidemiology of oral and oropharyngeal cancer. Oral Oncol [Internet]. Elsevier Ltd; 2009;45(4-5):309-16. Available from: http://dx.doi.org/10.1016/j.oraloncology.2008.06.002

29. Oluwatoyin LAWAL A, Kolude B, Folasade ADEYEMI B. International Journal of Medicine and Medical Sciences Oral cancer: The Nigerian experience. 2013;5(4):178-83. Available from: http://www.academicjournals.org/IJMMS

30. Kalyanyama BM, Matee MIN, Vuhahula E. Oral tumours in Tanzanian children based on biopsy materials examined over a 15-year period from 1982 to 1997. Int Dent J [Internet]. 2002;52(1):10-4. Available from: http://www.ncbi.nlm.nih.gov/pubmed/11933896

31. Petersen PE. Strengthening the prevention of oral cancer: The WHO perspective. Community Dent Oral Epidemiol. 2005;33(6):397-9.

32. Petersen PE. Oral cancer prevention and control - The approach of the World Health Organization. Oral Oncol [Internet]. Elsevier Ltd; 2009;45(4-5):454-60. Available from: http://dx.doi.org/10.1016/j.oraloncology.2008.05.023

33. Petti S. Lifestyle risk factors for oral cancer. Oral Oncol. 2009;45(4-5):340-50.

34. Vecchia C La, Tavani A, Franceschi S, Levi F, Corrao G, Negri EI. Epidemiology and Prevention of Oral Cancer. Oral Oncol. 1997;33(5):302-12. 
35. Bernadette, Arnold C, Christopher H, Modell. Global Report on Birth Defects - The Hidden Toll Of Dying and Disabled Children. March of Dimes. White Plains, New York; 2006.

36. Birth defects Report by the Secretariat. World Health Organization. 2010.

37. Penchaszadeh VB. Preventing congenital anomalies in developing countries. Community Genet. 2002;5(1):61-9.

38. Oginni FO. Orofacial Anomalies: Myths and Legends. Benin City; 2016. 1-106 p.

39. Dion K, Bersheid E, Walster E. What is beautiful is good. J Pers Soc Psychol. 1972;24(3):285-90.

40. Langlois JH, Kalakanis L, Rubenstein a J, Larson a, Hallam M, Smoot M. Maxims or myths of beauty? A meta-analytic and theoretical review. Psychol Bull. 2000;126(3):390-423.

41. Okkerse JME, Beemer FA, Cordia-de Haan M, Heineman-de Boer JA, Mellenbergh GJ, Wolters WHG. Facial attractiveness and facial impairment ratings in children with craniofacial malformations. Cleft Palate-Craniofacial J. 2001;38(4):386-92.

42. Markt JC, Lemon JC. Extraoral maxillofacial prosthetic rehabilitation the M. D. Anderson Cancer Center: a survey of patient attitudes and opinions. J Prosthet Dent. 2001;85(6):608-13.

43. Newton JT, Fiske J, Foote O, Frances C, Loh IM, Radford DR. Preliminary study of the impact of loss of part of the face and its prosthetic restoration. J Prosthet Dent. 1999;82:585-90.

44. Rumsey N, Harcourt D. Body image and disfigurement: Issues and interventions. Body Image. 2004;1(1):83-97.

45. Olasoji HO, Ugboko VI, Arotiba GT. Cultural and religious components in Nigerian parents' perceptions of the aetiology of cleft lip and palate: Implications for treatment and rehabilitation. $\mathrm{Br} \mathrm{J}$ Oral Maxillofac Surg. 2007;45(4):302-5.

46. Agbenorku P, Agbenorku M, Sefenu R, Matondo P, Osei D. Endemicity of cleft lip/palate in a rural community in South-East Ghana. J Sci Technol [Internet]. 2007;27(1):45-50. Available from: http://www.ajol.info/index.php/just/article/view/33023

47. Oginni FO, Asuku M, Oladele A, Obuekwe O, Nnabuko R. Knowledge And Cultural Beliefs About The Etiology And Management Of Orofacial Clefts In Nigeria’s Major Ethnic Groups. Cleft PalateCraniofacial J [Internet]. 2008;(September):100625070630097. Available from: http://www.cpcjournal.org/doi/abs/10.1597/07-085

48. Facing the World [Internet]. [cited 2015 Dec 12]. Available from: http://facingtheworld.net/

49. International Ocular Prosthetic Services (IOPS) [Internet]. [cited 2015 Dec 12]. Available from: http://www.customartificialeyes.org/

50. Comprehensive Community Based Rehabilitation in Tanzania (CCBRT) [Internet]. [cited 2015 Dec 12]. Available from: http://www.ccbrt.or.tz/home/

51. Eggbeer D. The Computer Aided Design and Fabrication of Facial Prostheses. Design. 2008;(March 2008):1-239.

52. Shrestha B, Goveas R, Thaworanunta S. Rapid fabrication of silicone orbital prosthesis using conventional methods. Singapore Dent J [Internet]. Elsevier; 2014;35:83-6. Available from: http://www.sciencedirect.com/science/article/pii/S037752911400011X

53. Thomas KF. Prosthetic Rehabilitation. London: Quintessence Publishing Co Ltd; 1994.

54. Leow ME, Pho RW. RTV silicone elastomers in hand prosthetics: properties, applications and 
techniques. Prosthet Orthot Int [Internet]. 1999;23(2):169-73. Available from:

http://www.ncbi.nlm.nih.gov/pubmed/10493145

55. Watson J, Cannavina G, Stokes CW, Kent G. A survey of the UK maxillofacial laboratory service: Profiles of staff and work. Br J Oral Maxillofac Surg. 2006;44(5):406-10.

56. Salazar-Gamarra R, Seelaus R, Da Silva JVL, Da Silva AM, Dib LL. Monoscopic photogrammetry to obtain 3D models by a mobile device: A method for making facial prostheses. J Otolaryngol - Head Neck Surg. 2016;45(1):1-13.

57. Goiato MC, Pesqueira AA, Ramos da Silva C, Filho HG, Micheline dos Santos D. Patient satisfaction with maxillofacial prosthesis. Literature review. J Plast Reconstr Aesthetic Surg. 2009;62(2):175-80.

58. Hatamleh MM, Watts DC. Bonding of maxillofacial silicone elastomers to an acrylic substrate. Dent Mater. 2010;26(4):387-95.

59. Hatamleh MM, Polyzois GL, Nuseir A, Hatamleh K, Alnazzawi A. Mechanical Properties and Simulated Aging of Silicone Maxillofacial Elastomers: Advancements in the Past 45 Years. J Prosthodont. 2016;25(5):418-26.

60. Zayed SM, Alshimy AM, Fahmy AE. Effect of surface treated silicon dioxide nanoparticles on some mechanical properties of maxillofacial silicone elastomer. Int J Biomater. Hindawi Publishing Corporation; 2014;2014(5):14-5.

61. Al-Harbi FA, Ayad NM, Saber MA, Arrejaie AS, Morgano SM. Mechanical behavior and color change of facial prosthetic elastomers after outdoor weathering in a hot and humid climate. J Prosthet Dent [Internet]. Editorial Council for the Journal of Prosthetic Dentistry; 2015;113(2):146-51. Available from: http://dx.doi.org/10.1016/j.prosdent.2014.09.008

62. Implications C, Chang T-LNREBJ. Treatment satisfaction with facial prostheses.pdf. J Prosthet Dent. 2005;94(September):275-80.

63. Eleni PN, Krokida MK, Polyzois GL. The effect of artificial accelerated weathering on the mechanical properties of maxillofacial polymers PDMS and CPE. Biomed Mater [Internet]. 2009;4(3):35001. Available from: http://www.ncbi.nlm.nih.gov/pubmed/19390144

64. Mitra A. Maxillofacial Prosthetic Materials- An Inclination Towards Silicones. J Clin Diagnostic Res. 2014;8-13.

65. Lai JH, Wang LL, Ko CC, Delong RL, Hodges JS. New organosilicon maxillofacial prosthetic materials. Dent Mater. 2002;18(3):281-6.

66. Lai JH, Hodges JS. Effects of processing parameters on physical properties of the silicone maxillofacial prosthetic materials. Dent Mater. 1999;15:450-5.

67. Hatamleh MM, Watts DC. Mechanical properties and bonding of maxillofacial silicone elastomers. Dent Mater. 2010;26(2):185-91.

68. Aziz T, Waters M, Jagger R. Analysis of the properties of silicone rubber maxillofacial prosthetic materials. J Dent. 2003;31(1):67-74.

69. Coward TJ, Seelaus R, Li SY. Computerized color formulation for African-Canadian people requiring facial prostheses: A pilot study. J Prosthodont. 2008;17(4):327-35.

70. Wright D. Failure of Plastics and Rubber Products: Causes, Effects and Cases Studies Involving Degradation. Shrewsbury Rapra Technology; 2001. 
71. Karakoca S, Aydin C, Yilmaz H, Bal BT. Retrospective study of treatment outcomes with implantretained extraoral prostheses: Survival rates and prosthetic complications. J Prosthet Dent. The Editorial Council of the Journal of Prosthetic Dentistry; 2010;103(2):118-26.

72. Leow MEL, Kour AK, Inglis TJJ, Kumarasinghe G, Pho RWH. Fungal colonisation in digital silicone rubber prostheses. Prosthet Orthot Int. 1997;21(3):195-8.

73. Vojdani M, Zibaei M, Aar K, Zomorodian K, Ma R, Boshehri S. In- vitro Study of the Effect of Clotrimazole Incorporation into Silicone Soft Liner on Fungal Colonization. 2009;9:19-23.

74. Ariani N, Visser A, Teulings MRIM, Dijk M, Rahardjo TBW, Vissink A, et al. Efficacy of cleansing agents in killing microorganisms in mixed species biofilms present on silicone facial prostheses - an in vitro study. Clin Oral Investig. 2015;19(9):2285-93.

75. Katz MR, Irish JC, Devins GM, Rodin GM, Gullane PJ. Psychosocial adjustment in head and neck cancer: the impact of disfigurement, gender and social support. Head Neck. 2003;25(February):103-12.

76. Bulbulian AH. Facial prosthesis. Philadelphia: W. B Saunder Company; 1945.

77. Hooper SM, Westcott T, Evans PLL, Bocca a. P, Jagger DC. Implant-supported facial prostheses provided by a maxillofacial unit in a U.K. regional hospital: Longevity and patient opinions. J Prosthodont. 2005;14(1):32-8.

78. Brook IM, Wood N, Brook M. Aetiology and incidence of facial fractures in adults. Int J Oral Surg. Munksgaard International Publishers Ltd.; 1983;12(5):293-8.

79. Fasola AO, Nyako EA, Obiechina AE, Arotiba JT. Trends in the characteristics of maxillofacial fractures in Nigeria. J Oral Maxillofac Surg. 2003;61(10):1140-3.

80. He Y, Xue G, Fu J. Fabrication of low cost soft tissue prostheses with the desktop 3D printer. Sci Rep [Internet]. 2014;4:6973. Available from:

http://www.pubmedcentral.nih.gov/articlerender.fcgi ?artid=4245596\&tool=pmcentrez\&rendertype=abstr act

81. Daniel S, Eggbeer D. A CAD and AM process for maxillofacial prostheses bar-clip retention. Rapid Prototyp J. 2016;22(1):170-7.

82. Feng Z, Dong Y, Zhao Y, Bai S, Zhou B, Bi Y, et al. Computer-assisted technique for the design and manufacture of realistic facial prostheses. Br J Oral Maxillofac Surg [Internet]. British Association of Oral and Maxillofacial Surgeons; 2010;48(2):105-9. Available from: http://dx.doi.org/10.1016/j.bjoms.2009.05.009

83. Jindal SK, Sherriff M, Waters MG, Coward TJ. Development of a 3D printable maxillofacial silicone: Part I. Optimization of polydimethylsiloxane chains and cross-linker concentration. J Prosthet Dent [Internet]. Editorial Council for the Journal of Prosthetic Dentistry; 2016;116(4):617-22. Available from: http://dx.doi.org/10.1016/j.prosdent.2016.02.020

84. Xiao K, Zardawi F, Van Noort R, Yates JM. Developing a 3D colour image reproduction system for additive manufacturing of facial prostheses. Int J Adv Manuf Technol. 2014;70(9-12):2043-9.

85. Xiao K, Zardawi F, Van Noort R, Yates JM. Color reproduction for advanced manufacture of soft tissue prostheses. J Dent. 2013;41(SUPPL.5).

86. Filie Haddad M, Coelho Goiato M, Micheline Dos Santos D, Moreno A, Filipe D’almeida N, Alves Pesqueira A. Color stability of maxillofacial silicone with nanoparticle pigment and opacifier submitted 
to disinfection and artificial aging. J Biomed Opt. 2011;16(9):95004.

87. Han Y, Kiat-amnuay S, Powers JM, Zhao Y. Effect of nano-oxide concentration on the mechanical properties of a maxillofacial silicone elastomer. J Prosthet Dent [Internet]. The Editorial Council of the Journal of Prosthetic Dentistry; 2008;100(6):465-73. Available from: http://dx.doi.org/10.1016/S00223913(08)60266-8

88. Karayazgan B, Gunay Y, Evlioğlu G. Improved edge strength in a facial prosthesis by incorporation of tulle: A clinical report. J Prosthet Dent. 2003;90(6):526-9.

89. Gunay Y, Kurtoglu C, Atay A, Karayazgan B, Gurbuz CC. Effect of tulle on the mechanical properties of a maxillofacial silicone elastomer. Dent Mater J [Internet]. 2008;27(6):775-9. Available from: http://www.ncbi.nlm.nih.gov/pubmed/19241684

90. Hu X, Pan X, Johnston WM. Effects of pigments on dynamic mechanical properties of a maxillofacial prosthetic elastomer. J Prosthet Dent [Internet]. Editorial Council for the Journal of Prosthetic Dentistry; 2014;112(5):1298-303. Available from: http://dx.doi.org/10.1016/j.prosdent.2014.04.004

91. Bellamy K, Limbert G, Waters MG, Middleton J. An elastomeric material for facial prostheses: Synthesis, experimental and numerical testing aspects. Biomaterials. 2003;24(27):5061-6.

92. Liu Q, Shao L, Fan H, Long Y, Zhao N, Yang S, et al. Characterization of maxillofacial silicone elastomer reinforced with different hollow microspheres. J Mater Sci. 2015;50(11):3976-83.

93. Bi Y, Wu S, Zhao Y, Bai S. A new method for fabricating orbital prosthesis with a CAD / CAM negative mold. J Prosthet Dent [Internet]. 2013;110(5):424-8. Available from: http://dx.doi.org/10.1016/j.prosdent.2013.05.003

94. Bibb R, Eggbeer D, Evans P. Rapid prototyping technologies in soft tissue facial prosthetics: current state of the art. Rapid Prototyp J. 2010;16(2):130-7.

95. Ciocca L, Mingucci R, Gassino G, Scotti R. CAD/CAM ear model and virtual construction of the mold. J Prosthet Dent. 2007;98(5):339-43.

96. Goiato MC, Santos MR, Pesqueira AA, Moreno A, dos Santos DM, Haddad MF. Prototyping for surgical and prosthetic treatment. J Craniofac Surg. 2011;22(3):914-7.

97. Watson J, Hatamleh MM. Complete integration of technology for improved reproduction of auricular prostheses. J Prosthet Dent [Internet]. The Editorial Council for the Journal of Prosthetic Dentistry; 2014;111(5):430-6. Available from: http://dx.doi.org/10.1016/j.prosdent.2013.07.018

98. Sansoni G, Cavagnini G, Docchio F, Gastaldi G. Virtual and physical prototyping by means of a 3D optical digitizer: Application to facial prosthetic reconstruction. Virtual Phys Prototyp [Internet]. 2009;4(October):217-26. Available from: http://search.ebscohost.com/login.aspx?direct=true\&db=a9h\&AN=45584151\&lang=cs\&site=ehost-live 


\section{Tables}

Table 1: Keywords, themes and search engines utilised in study

Table 2: Demographics of participants interviewed

Table 3: Patterns of some maxillofacial injuries by trauma in resource limited areas 
Table 1: Keywords, themes and search engines utilised in study

\begin{tabular}{|l|l|}
\hline Keywords & $\begin{array}{l}\text { 'maxillofacial prostheses'; 'facial prostheses'; 'maxillofacial injuries'; } \\
\text { 'developing country'; 'resource limited'; 'Africa'; 'Asia' and 'South America' }\end{array}$ \\
\hline Engine & $\begin{array}{l}\text { Loughborough University library [for access to books, electronic and print } \\
\text { journals articles]; SCONUL [Society of College national and university } \\
\text { libraries]; 'medline'; 'compendex'; 'sciencedirect'; 'google scholar' and } \\
\text { 'researchgate' }\end{array}$ \\
\hline $\begin{array}{l}\text { Themes } \\
\text { from }\end{array}$ & $\begin{array}{l}\text { 'maxillofacial prosthetics and technology'; } \\
\text { 'processing and manufacturability of maxillofacial prostheses'; } \\
\text { 'material development for maxillofacial prostheses'; } \\
\text { 'maxillofacial prostheses development in resource limited areas' }\end{array}$ \\
\hline
\end{tabular}


Table 2: Demographics of participants interviewed

\begin{tabular}{|c|c|c|c|}
\hline $\begin{array}{l}\text { PARTICIPANT } \\
\text { /GENDER }\end{array}$ & $\begin{array}{c}\text { JOB } \\
\text { TITLE }\end{array}$ & $\begin{array}{l}\text { EXPERIENCE } \\
\text { LEVEL }\end{array}$ & $\begin{array}{l}\text { CURRENT WORK } \\
\text { LOCATION }\end{array}$ \\
\hline Participant 1/Female & Mechanical Engineer & $\geq 2.5$ years & South Africa \\
\hline Participant 2/Male & $\begin{array}{l}\text { Reader/Consultant } \\
\text { Maxillofacial \& Cranial } \\
\text { Rehabilitation }\end{array}$ & $\geq 30$ years & United Kingdom \\
\hline Participant 3/Male & $\begin{array}{l}\text { Consultant Maxillofacial } \\
\text { Prosthetist }\end{array}$ & $\geq 30$ years & United Kingdom \\
\hline Participant 4/Male & Maxillofacial Prosthetist & $\geq 30$ years & United Kingdom \\
\hline Participant 5/Female & $\begin{array}{l}\text { Research } \\
\text { Fellow/Reconstructive Scientist }\end{array}$ & $\geq 25$ years & United Kingdom \\
\hline Participant 6/Male & $\begin{array}{l}\text { Rehabilitation } \\
\text { Bucomaxillofacial specialist }\end{array}$ & $\geq 7$ years & Peru/Brazil \\
\hline
\end{tabular}


Table 3: Patterns of some maxillofacial injuries by trauma in resource limited areas

\begin{tabular}{|c|c|c|c|c|c|c|c|c|c|}
\hline \multirow{2}{*}{$\begin{array}{l}\text { First } \\
\text { Author, } \\
\text { Year }\end{array}$} & \multirow{2}{*}{$\begin{array}{l}\text { Countr } \\
\mathbf{y}\end{array}$} & \multirow{2}{*}{$\begin{array}{l}\text { Numb } \\
\text { er } \\
\text { of } \\
\text { Cases }\end{array}$} & \multicolumn{6}{|c|}{ Aetiology Factors [\%] } & \multirow{2}{*}{$\begin{array}{l}\text { Site of Fracture } \\
\text { Soft tissue |injuries }\end{array}$} \\
\hline & & & $\begin{array}{l}\text { Road } \\
\text { Cras } \\
\text { hes }\end{array}$ & $\begin{array}{l}\text { Violen } \\
\text { ce/Ass } \\
\text { ault }\end{array}$ & $\begin{array}{l}\text { Industri } \\
\text { al }\end{array}$ & $\begin{array}{l}\text { Sport } \\
\text { S }\end{array}$ & Falls & $\begin{array}{l}\text { Othe } \\
\text { rs }\end{array}$ & \\
\hline $\begin{array}{l}\text { Chalya, } \\
2011[19]\end{array}$ & $\begin{array}{l}\text { Tanzan } \\
\text { ia }\end{array}$ & 154 & 57.1 & 16.2 & - & 2.6 & 14.3 & 9.7 & $\begin{array}{l}92.2 \text { soft tissues injuries which } \\
\text { included contusion, lacerations, } \\
\text { abrasions and burns. Majority of } \\
\text { the soft tissue injuries were } \\
\text { located extra orally } 83.1 \%\end{array}$ \\
\hline $\begin{array}{l}\text { Schaftenaar, } \\
2009 \\
{[5]}\end{array}$ & & 532 & 42.3 & $40.6+$ & $3.9 \%$ & 4.9 & 6.6 & 1.7 & $\begin{array}{l}\text { Cut wound - } 45 \% \\
\text { Contusion - } 22.9 \% \text {, Laceration - } \\
\text { 17.7\%, Hematoma - } 6.1 \% \text {, } \\
\text { Excoriation/abrasion - } 4.3 \% \text {, } \\
\text { Puncture wound - } 2.6 \% \text {, Avulsion } \\
-1 \% \text {, Burns - } 0.3 \%\end{array}$ \\
\hline $\begin{array}{l}\text { Bali, } 2013 \\
\text { [17] }\end{array}$ & India & 740 & 71.89 & 5.6 & - & 2.8 & 16.2 & - & Nasal - $1.3 \%$ \\
\hline $\begin{array}{l}\text { Khitab., } \\
2010 \\
{[21]}\end{array}$ & & 340 & 45.29 & 4.11 & 0.88 & 2.35 & 29.7 & 3.23 & \\
\hline $\begin{array}{l}\text { Shah, } 2006 \\
\text { [26] }\end{array}$ & & 320 & 64.7 & - & 0.6 & 5.3 & 18.8 & 1.6 & \\
\hline $\begin{array}{l}\text { Leles, } 2010 \\
{[22]}\end{array}$ & Brazil & 530 & 45.7 & 24.3 & - & 6.6 & 17.7 & 5.7 & $\begin{array}{l}\text { Soft tissue injury in } 73 \text { patients } \\
\text { [13.8\%], mainly abrasion } n-43 \\
\text { edema } n-25 \text {, }\end{array}$ \\
\hline $\begin{array}{l}\text { Kamulegeya } \\
\text {, } 2009 \text { [20] }\end{array}$ & Uganda & 132 & 56.06 & 37.11 & 3.03 & 3.79 & - & - & - \\
\hline $\begin{array}{l}\text { Ugboko, } \\
1998 \\
{[15]}\end{array}$ & Nigeria & 442 & 72.8 & 8.4 & 2.0 & 3.2 & 10.9 & 3.6 & $\begin{array}{l}\text { Soft tissue laceration of the face - } \\
62.2 \text {. Tongue laceration - } 1.1\end{array}$ \\
\hline $\begin{array}{l}\text { Ukpong, } \\
2008 \\
{[24]}\end{array}$ & & 126 & 84 & 6 & & & 5 & & Soft tissue injury $17 \%$ \\
\hline $\begin{array}{l}\text { Adebayo, } \\
2003 \text { [25] }\end{array}$ & & 443 & 56 & 13 & 3 & 5 & 24 & - & - \\
\hline $\begin{array}{l}\text { Adekeye, } \\
1980[13]\end{array}$ & & 1447 & 75.6 & - & $7.9^{+}$ & 1.3 & $7.9^{+}$ & 2.4 & - \\
\hline
\end{tabular}

${ }^{+}$: falls and industrial included/ shaded portion not in percentages 